The Genetic Gods 



\section{The Genetic Gods \\ Evolution and Belief in Human Affairs}

\section{John C. Avise}

Harvard University Press

Cambridge, Massachusetts and London, England, 1998 
Copyright (C) 1998 by the President and Fellows

of Harvard College

All rights reserved

Printed in the United States of America

Permission has been granted by the publisher to quote from Old Turtle by Douglas Wood (Duluth, Minn.: Pfeifer-Hamilton Publishers, 1992).

\section{Library of Congress Cataloging-in-Publication Data}

Avise, John C.

The genetic gods : evolution and belief in human affairs / John C. Avise.

p. $\mathrm{cm}$.

Includes bibliographical references and index.

ISBN 0-674-34625-4 (cloth : alk. paper)

1. Genetics-Popular works.

2. Evolutionary genetics-Popular works.

I. Title.

QH437.A95 1998

576-dc21 98-3255 